Pomáhajúce profesie, roč. 2, č. 1, 2019, 37-52

\title{
SPOKOJNOSŤ A VÝZNAMNOSŤ - ASPEKTY KVALITY ŽIVOTA A PRACOVNÁ IDENTITA MLADÝCH L'UDÍ
}

\author{
Katarína Baňasová ${ }^{\text {, Marianna Hostovičáková }}{ }^{2}$ \\ Ústav aplikovanej psychológie FSVaZ UKF Nitra', \\ Katedra psychologických vied² FSVaZ UKF Nitra, \\ katkabanas@gmail.com
}

\begin{abstract}
Abstrakt: Základná koncepcia, z ktorej v našej práci vychádzame je model pracovnej identity podl’a Porfeliho (2011). Pri kvalite života sme vychádzali z koncepcií, ktoré ju vnímajú ako hodnotenie významu a spokojnosti s oblast’ami života. Išlo o hodnotenie dôležitosti a spokojnosti s piatimi oblast’ami života: zdravie, vol'ný čas, základné potreby, abstraktné hodnoty a blízke vzt'ahy. Ciel’om našej práce bolo definovat' vzt'ah medzi kvalitou života a pracovnou identitou u mladších dospelých. Výskumný súbor pozostával zo 102 participantov (57 žien, 45 mužov) vo veku od 20 do 30 rokov $(M=24,7 ; \quad S D=3,11)$. Meranie pracovnej identity sme realizovali dotazníkom Vocational Identity Status Assesment (VISA). Na meranie kvality života sme použili dotazník Subjective Quality of Life Analysis (SQUALA). Výsledkom našej práce je zistenie, že u mladších dospelých existuje súvislost' pracovnej identity a kvality života. Pozitívna súvislost' existuje medzi oboma kategóriami kariérového záväzku i prieskumu a kvalitou života. Negatívna súvislost' je medzi sebapochybnost'ami a kvalitou života. Medzi flexibilitou a kvalitou života sa nepreukázal štatisticky významný vzt’ah. Významné vzt’ahy sme zistili aj medzi niektorými kategóriami kariérového skúmania, záväzku, prehodnotenia a hodnotením dôležitosti a spokojnosti s niektorými oblast'ami života.
\end{abstract}

Kl'účové slová: spokojnost', významnost', kvalita života, pracovná identita

\section{1 ÚVOD}

Kariéra, ktorú si človek zvolí, podstatne zasahuje do celého života. Skutočnost', ako človek vníma seba v pracovnom kontexte, mení jeho nazeranie na významnost' a spokojnost' s určitými oblast’ami v jeho živote. V predchádzajúcich výskumoch sa pracovná identita spájala s rôznymi premennými, často išlo o premenné ako vel'ká pät'ka osobnostných vlastností, (Oleś, 2015) psychická pohoda (De Goede, Spruijt, Iedema, \& Meeus, 1999), či well-being (Karaś, Cieciuch, 2018). My sme sa rozhodli, že sa zameriame na jednotlivé dimenzie, ktoré tvoria pracovnú identitu podl'a Porfeliho taxonómie (Porfeli, 2011) v súvislosti s kvalitou života. Z predchádzajúcich výskumov je možné usudzovat', že dané dimenzie sú vo vzt’ahu so spokojnost'ou so životom alebo well-beingom (Karaś, Cieciuch, 2018; Luyckx., Schwartz, Berzonsky, Soenens, Vansteenkiste, Smits, \& Goossens, 2008; Oleś, 2015). Rozhodnutie o kariére a výber konkrétnej kariéry je najvýznamnejšou úlohou mladých l'udí. Predchádzajúce výskumy sa zameriavali na študentov vysokých (Pofeli, Lee, Vondracek, \& Weigold, 2011) a stredných škôl (Baňasová, K., Sollár, T., \& Sollárová, 2016). Náš výskumný súbor pozostával z mladších dospelých, a teda l'udí vo veku 20-30 rokov.

\subsection{Psychologické modely kvality života}

Kvalita života ako koncept je odlišne chápaná z pohl’adu psychológie, medicíny či sociológie. V sociologickom vnímaní kvality života sa zdôrazňujú znaky sociálnej úspešnosti, ktorými sú status, 
majetok, zariadenie domácnosti, rodinný stav a vzdelanie. Významným pojmom je životná úroveň, čiže kvalita a kvantita služieb a tovarov, ktoré majú l’udia k dispozícii. V medicíne sa zdôrazňuje zist'ovanie kvality života v oblasti psychosomatického a fyzického zdravia. Využíva sa tu kvalita života ovplyvnená zdravím (Švehlíková, \& Heretik, 2008). Psychologické chápanie kvality života na ktoré sa v štúdii budeme zameriavat’ zdôrazňuje spokojnost' so životom a životnú pohodu, ktorá je prežívaná subjektívne.

Model spokojnosti chápe ako prvoradú charakteristiku kvality života spokojnost', ktorej hodnotenie je najčastejšie používané v metodikách posudzujúcich kvalitu života (Babinčák, 2008). Rozdielový model je založený na chápaní kvality života ako rozdielu či diskrepancie medzi rôzne určenými očakávaniami človeka a realitou, čiže súčasným stavom, a to v určitom časovom období, čo znamená, že v určitej situácii a v určitom čase (Babinčák, 2013). Centrum pre podporu zdravia Univerzity v Toronte vytvoril svoj koncepčný model kvality života, ktorý je multidimenzionálny a predpokladá, že kvalita života je holistická (Babinčák, 2008). Kováč (2004) zdôrazňuje rozdielne nazeranie na kvalitu života jednotlivcov, vzhl'adom na rasu, geografickú lokalitu či socioekonomický status. Veenhovenov model (2000) štyroch kvalít života zas definuje viac typov kvalít života. V našej práci však budeme vychádzat’ z kombinovaného modelu - modelu spokojnosti a významu, ktorý opíšeme v samostatnej kapitole.

\subsubsection{Model spokojnosti a významnosti}

Kombinovaný model kvality života spája zist’ovanie spokojnosti s jednotlivými oblast'ami života s významnost'ou týchto oblastí. V samostatnom modeli spokojnosti sa predpokladá, že jednotlivé oblasti majú rovnakú dôležitost' pre celkovú kvalitu života. Model nerieši, či niektorá oblast' je viac významná pre celkovú kvalitu života ako iná oblast'. Taktiež neberie do úvahy rozdiely vo významnosti pre jednotlivých l'udí. Kombinovaný model teda zahŕňa individuálne odlišnú významnost' rôznych oblasti života a posudzuje ich na základe spokojnosti (Babinčák, 2008).

V štúdii ku kvalite života pristupujeme podl'a kombinovaného modelu spokojnosti a významu. Hodnotenie sa realizuje v piatich oblastiach: zdravie, blízke vzt’ahy, abstraktné hodnoty, vol'ný čas a základné potreby. Práve spomínané dve zložky (významnost' a spokojnost'), z ktorých kombinovaný model kvality života pozostáva, nám umožňuje skúmat’ separátne obe zložky kvality života, a tak zároveň detailnejšie popísat' koncept kvality života.

\subsection{Pracovná identita}

Holland (1997) charakterizuje pracovnú identitu ako ucelený a stály obraz ciel'ov, talentov a záujmov, ktorým je potrebné venovat' pozornost', nakol'ko sú dôležité v rámci kariérových volieb človeka (Hudáková, Sollár, 2018). Psychologický model, ktorý nazývame pracovná identita sa vyvinul z modelu ego identity, ktorý prechádzal zmenami. Tvoril tak základ, z ktorého vychádzal Porfeli (2011) pri koncipovaní svojej koncepcie pracovnej identity. Spojil tak pri tvorbe taxonómie zložiek pracovnej identity teórie a modely Marcie (1996), Luyckxa et al (2005) a Crocettiovej, Rubiniho a Meeusa (2008).

Marcia (1996) založil svoj model na teórii psychosociálneho vývinu Eriksona. Ego identita a difúzia identity sa týkajú psychosociálnej krízy, ku ktorej dochádza v neskorej adolescencii. Pracoval najmä s konštruktom krízy a záväzku. Vkríze ide o aktívne hl'adanie a rozhodovanie sa o záväzkoch identity, spôsobené spochybňovaním hodnôt a ciel'ov, ktoré boli predtým definované rodičmi. Neskôr sa kríza začala označovat' ako skúmanie, pretože ide o proces, ktorý vedie k výberu ciel'ov, hodnôt a presvedčení (Marcia, 1966). Porfeliho model zachoval z modelu Luyckxa et al. (2005) dve dimenzie: skúmanie (do híbky a do šírky) a záväzok (identifikácia záväzku a vytváranie záväzku). Pridal dimenziu prehodnotenie záväzku z modelu Crocettiovej, Rubiniho a Meeusa (2008), ktorú premenoval na prehodnotenie kariéry. Dimenziu prehodnotenie kariéry rozdelili na 
flexibilitu kariérového záväzku a kariérovú sebapochybnost'. Na základe spomínaných dimenzií identifikoval šest' statusov pracovnej identity, ktorými sú dosiahnutý status, predčasne uzavretý status, status moratória, moratórium v štádiu hl'adania, rozptýlený status a nediferencovaný status.

Mladá dospelost' je významným obdobím v živote človeka aj z dôvodu, že sa l'udia pripravujú na svet práce (Super, 1980). V tomto období sa okrem pracovnej identity rozvíja aj kariéra mladého človeka. Koncept pracovnej identity identifikuje jednotlivca rôzne celistvého v rámci viacerých oblastí, ktoré viac či menej ovplyvňujú adaptívne rozhodovanie ohl'adom d'alšej kariéry (Baňasová et al., 2016).

Erikson (1959) uviedol, že rozvoj pracovnej identity býva najnáročnejším a najt’ažším aspektom pri formovaní identity počas prechodu od dospievania k dospelosti. Z pozorovania tiež vyplynulo, že vytvorenie pracovnej identity a výber kariéry patria k prvoradým úlohám mladých l’udí prechádzajúcich do dospelosti. Pracovná identita predstavuje najdôležitejšiu úlohu adolescentov v celkovom rozvoji identity (Lee, Vondracek, \& Weigold, 2011). Vytvorenie zrelej pracovnej identity je znakom dobrého zdravia jednotlivca (Malanchuk, Messersmith, \& Eccles 2010). U dospievajúcich a mladých dospelých súvisí so psychickým zdravím a s vysokou úrovňou životnej spokojnosti, najmä v oblasti kariérových záväzkov (Hirschi, 2011).

Pracovná identita sa formuje získavaním kariérových zručností a skúšaním rôznych kariérových ciest. Pochybnosti o zvolenom študijnom a kariérovom programe sú prirodzeným procesom každého jednotlivca (Smitina, 2010). Takýto proces nie je ukončený raz a navždy, avšak v súlade s Eriksonovou teóriou sa uvádza, že pracovná identita sa s vekom zvyšuje (Holland, Gottfredson, Power, 1980). Adolescenti a mladí dospelí si potrebujú objasnit' svoje povolanie, resp. svoju profesijnú identitu a potrebujú sa orientovat' vo svojej budúcej kariérovej ceste, aby uspeli v práci a v živote (Super, 1974). Výsledky výskumov tiež naznačujú, že profesijný rozvoj je spojený s dosiahnutím zrelej pracovnej identity (Lee, Vondracek, \& Weigold, et al., 2011). Iní autori ponímajú koncept nielen vo vzt’ahu k rozhodovaniu o budúcnosti, ale aj k pocitu príslušnosti k určitému povolaniu a uvedomeniu si vlastných schopností a profesionality (Smitina, 2010).

\subsubsection{Porfeliho model pracovnej identity}

Najnovší model pracovnej identity je založený na troch prvkoch: na skúmaní, kariérovom záväzku a kariérovom prehodnotení (Lee, Vondracek, \& Weigold, 2011). Ide o dimenzie, ktoré sa d'alej členia na konkrétne aspekty pracovnej identity. Dimenzia kariérového záväzku pozostáva z rovnomenného aspektu - kariérového záväzku a identifikácie s kariérovým záväzkom. V prípade aspektu kariérového záväzku ide o pevné rozhodnutie o kariérovej ceste. Identifikácia s kariérovým záväzkom je charakteristická stotožnením sa s danou vol'bou (Porfeli et al., 2011). Do oblasti kariérového prehodnocovania zahŕňame kariérovú flexibilitu, ktorá v Porfeliho (Lee, Vondracek, \& Weigold, 2011) poňatí pracovnej identity netvorí adaptívnu dimenziu, ako by sme to mohli z názvu mylne dedukovat'. Ide o mieru neurčitosti ohl'adne budúceho vývinu kariérovej vol'by a momentálneho rozhodnutia. Prehodnocovanie obsahuje tiež oblast' kariérových sebapochybností, ktorých paralelu vnímame tiež v oblasti t’ažkostí s rozhodovaním, ako ich definovali Gati, Krausz a Osipow (1996). Čo sa týka aspektu skúmania (explorácie), ide o oblast' skúmania možností povolaní, tak „do šírky“, ako aj „do hĺbky“ existujúcich možností. Paralelu s touto oblast'ou, vnímame v rámci taxonómií Gatiho, Krausza a Osipowa (1996), resp. Saka, Gatiho a Kellyho (2008).

Rozoznávame šest' statusov pracovnej identity: ako adaptívnu formu statusu označujeme Dosiahnutý status (Achieved), ktorý je založený na záväzku a hl'adaní možností, je charakteristický nízkou kariérovou flexibilitou. Uzavretý status pracovnej identity (Foreclosed) je status založený na záväzku bez toho, aby jednotlivec hl'adal kariérové možnosti, a to najmä čo sa týka aspektu 
explorácie „do šírky“. Moratórium (Moratorium) je hladanie bez záväzku a so strednou hodnotou kariérovej flexibility. Rozptýlený status (Diffused) zahŕňa nízke hodnoty hl'adania a záväzku. Moratórium v štádiu hl'adania (Searching Moratorium) je status označovaný ako „predbežný záväzok“, pretože spadá niekde medzi Dosiahnutý status a status Moratória, je charakteristický vysokým záväzkom a značnou kariérovou flexibilitou. Nediferencovaný status (Undifferentiated) je charakteristický nevyhranenost’ou jednotlivca a nedá sa zaradit' do žiadneho zo statusov (Porfeli, \& Savickas, 2012).

\subsection{Pracovná identita ako kl'účový aspekt hodnotenia kvality života}

Ukazuje sa, že čím ucelenejší status identity, tým vyššia psychická pohoda (De Goede, Spruijt, Iedema, \& Meeus, 1999). Napríklad l'udia s dlhodobým stavom difúznej identity, ktorý pretrváva vo veku 29 rokov, popisovali príznaky psychického distresu. Odrazilo sa to na ich prístupe k zmene životných podmienok a rozsahu vakom sa zapájajú do vytvárania zmyslu a ako rozvíjajú svoj osobný smer života. K zmene životných podmienok pristupovali so zníženou aktivitou, neochotou a neschopnost'ou preskúmavat' alternatívy alebo robit' záväzky. Chcú sa vyhnút' alebo nie sú schopní prieskumu a vytvárania záväzku v meniacich sa podmienkach. Skúmanie dlhodobej difúznej identity naznačuje, že sa postupom času môže rozširovat' počet osôb v bezstarostnej difúzii (Carlsson, Wängqvist, Frisén, 2016). Crocettiová (2011, In Crocetti, Avanzi, Hawk, Fraccaroli, Meeus, 2014) uvádza, že pracujúci mladí l'udia v statuse moratória majú nižšiu spokojnost' so životom ako l'udia v statuse predčasného uzavretia či v statuse dosiahnutia identity. Pracovná identita pôsobí ako významný zdroj zmyslu života a úzko súvisí so sebaúctou. Vnímanie zmyslu, sebajasnost' a sabaúcta sú zase dôležitými predchodcami životnej spokojnosti a wellbeingu. Pričom výskum zameraný na zistenie vzt’ahu medzi dosiahnutou pracovnou identitou a životnou spokojnost'ou u adolescentov potvrdil, že pracovná identita môže byt' vysvetl'ujúca premenná pre životnú spokojnost' (Hirschi, 2011).

Výskumy zamerané na zist'ovanie vzt'ahov medzi dimenziami pracovnej identity a well-beingom či životnou spokojnost'ou ukazujú, že záväzok pozitívne koreluje s well-beingom (Berzonsky, 2003; Hardy et al., 2013; Ritchie et al., 2013 In Karaś, Ciecuch, 2018). S well-beingom pozitívne súvisí taktiež hlboké skúmanie možností, no naopak prehodnotenie má negatívnu súvislost' (Karaś, Cieciuch, 2018). V extrémnych prípadoch by mohla kariérová pochybnost' vyvolat' chronickú kariérovú nerozhodnost' a znížit' well-being (Porfeli, Lee, 2012). Aj v iných výskumoch negatívnu úlohu pri dosahovaní well-beingu zohráva prehodnotenie záväzku (Meeus, 2011, In Karaś, Cieciuch, 2018). Prehodnotenie je spojené s nízkou úrovňou životnej spokojnosti i well-beingu. Záväzok súvisí s vysokou úrovňou pozitívneho well-beingu a životnou spokojnost'ou (Karaś et al., 2015; Sugimura et al., 2015, In Dimitrova, Buzea, Taušová, Uka, Zakaj, \& Crocetti, 2017). Ukazuje sa, že tí čo majú väčšiu istotu a záväzok ku kariérovej vol'be, majú vyššiu úroveň spokojnosti so životom aj pozitívnejšie emócie. Rovnako, že kariérové skúmanie významne súvisí so spokojnost'ou so životom (Demirtas, \& Tezer, 2012). Iná štúdia preukázala, že skúmanie do hĺbky aj do šírky je prepojené s well-beingom (Luyckx, Schwartz, Berzonsky, Soenens, Vansteenkiste, Smits, \& Goossens, 2008).

Karaś, Cieciuch (2018) zist’ovali či záväzok, prehodnotenie záväzku a skúmanie do hĺbky je spojené s well-beingom vo viacerých životných oblastiach. Zistenia naznačujú, že záväzok a skúmanie do hĺbky je pozitívne spojený s mnohými oblast’ami. Naopak, prehodnotenie záväzku nemá súvislost' s týmito oblast'ami. Demirtasová a Tezerová (2012) sa zamerali na zistenie súvislosti medzi spokojnost'ou s romantickými vzt'ahmi a kariérovým prieskumom i záväzkom ku kariérovej vol'be na vzorke univerzitných študentov. Výsledkom bolo, že spokojnost' s romantickými vzt’ahmi negatívne koreluje s kariérovým prieskumom a záväzkom. Dosiahnutie zmyslu pre záväzok a jasnost' identity pozitívne súvisia s vyššou pohodou. Teda neschopnost' dosiahnut' zmysel 
pracovnej identity môže mat' negatívne následky na životnú spokojnost' (Hirchi, 2012). Ciel'om našej práce je teda definovat' vzt'ah medzi kvalitou života (významnost'ou a spokojnost'ou s rôznymi oblast'ami života) a pracovnou identitou u mladších dospelých. Pričom na základe adaptívnosti dimenzií pracovnej identity budeme predpokladat' negatívnu/pozitívnu významnú súvislost' s celkovou kvalitou života. V prípade vzt'ahov zložiek kvality života (významnosti a spokojnosti) s pracovnou identitou si kladieme otvorenú otázku či nachádzame medzi spomínanými konceptami významné vzt’ahy.

\section{METÓDY}

\subsection{Výskumný súbor}

Výskumný súbor pozostával z mladších dospelých, čo zahŕňa l'udí vo veku od 20 do 30 rokov. Počet participantov bol $n=102,57$ žien (55,9 \%) a 45 mužov (44,1 \%). Priemerný vek participantov bol $\mathrm{M}_{\mathrm{vek}}=24,7 \operatorname{rokov}(\mathrm{SD}=3,11)$.

Zamerali sme sa na l'udí, ktorí sú už zapojení do pracovného procesu. Napriek tomu sa v našej vzorke nachádzajú niekol'kí momentálne nepracujúci participanti $(10,8 \%)$. Väčšina participantov ukončila stredné odborné vzdelanie s maturitou alebo gymnázium $(54,9 \%)$. Najviac participantov pracuje voblasti zdravotníctva $(17,6)$, za nimi nasledujú učitelia $(14,3 \%)$ a zamestnanci bezpečnostných zložiek (13,2\%). Priemerná dížka súčasného zamestnania je 21,5 mesiaca (SD = 24).

\subsection{Meracie nástroje}

\section{Dotazník SQUALA (Zanotti, Pringuey, 1992)}

Kvalitu života sme zist'ovali dotazníkom SQUALA - Subjective Quality of Life Analysis. Zarad'uje sa medzi sebaposudzovacie dotazníky a koncepčne sa opiera o Maslowovu teóriu potrieb. Dotazník zachytáva subjektívne nazeranie človeka na jeho životnú situáciu tak, že človek hodnotí nakol'ko je spokojný alebo nespokojný s oblast'ami života, ktoré sú pre neho dôležité.

Parciálne skóre sa odvíja od daných oblastí života a získa sa ako súčin skóre spokojnosti a skóre významnosti (dôležitosti). Môže dosahovat' hodnoty 0-20. Tieto výsledky je možné zobrazit’ ako profil kvality života. Hrubé skóre sa vzt’ahuje na jednotlivé dimenzie dotazníka a to: zdravie, vol'ný čas, abstraktné hodnoty, blízke vzt’ahy a základné potreby (Chrastina, Ivanová, Krejčířová, \& Ježorská, 2014).

\section{Dotazník VISA (Porfeli, 2011)}

Na meranie pracovnej identity sme si zvolili dotazník VISA (Vocational Identity Status Assesment, 2011). Obsahuje 30 položiek, 10 pre každú dimenziu, 5 pre každú subškálu. Každá položka sa hodnotí na 5-bodovej Likertovej škále od 1=rozhodne nesúhlasím do 5=rozhodne súhlasím (Lee, Vondracek, \& Weigold, 2011).

Dotazník má tri dimenzie, ktoré sa delia na dve podskupiny: kariérové skúmanie na skúmanie do híbky a do šírky, kariérový záväzok na tvorbu záväzku a identifikáciu so záväzkom a prehodnotenie kariéry na kariérovú sebapochybnost' a flexibilitu. Dotazník rozoznáva šest' statusov pracovnej identity: Dosiahnutý status (Achieved), Uzavretý status pracovnej identity (Foreclosed), Moratórium (Moratorium), Rozptýlený status (Diffused), Moratórium v štádiu hl'adania (Searching Moratorium) a Nediferencovaný status (Undifferentiated). 


\subsection{Spracovanie dát}

Dáta sme spracovali štatistickým programom IBM SPSS Statistics 21. Vzhl’adom na korelačný dizajn štúdie sme pri premenných, ktoré vykazovali normálny tvar distribúcie použili Pearsonov koeficient súčinovej korelácie (r). U premenných, ktoré nedosiahli normálny tvar distribúcie sme použili Spearmanov koeficient poradovej korelácie $\left(r_{s}\right)$. Pri vytváraní klastrov sme použili k-means zhlukovú analýzu.

\section{VÝSLEDKY}

Výsledky uvádzame v nasledujúcich tabul'kách, ktoré popisujú vzt’ah jednotlivých dimenzií pracovnej identity (kariérového záväzku, kariérového prehodnotenia a skúmania), kvality života a jej zložiek (významnosti s oblast’ami života a spokojnosti s nimi). Uvádzame tiež výsledky zhlukovej analýzy a deskriptívnu analýzu statusov pracovnej identity v našej výskumnej vzorke.

Tab 1 Korelácia celkovej kvality života s dimenziami kariérového záväzku $(n=102)$

\begin{tabular}{lcc}
\hline \multicolumn{1}{c}{ Dimenzie pracovnej identity } & \multicolumn{2}{c}{ Kvalita života } \\
& $\mathrm{r} / \mathrm{r}_{\mathrm{s}}$ & $\mathrm{p}$ \\
\hline Tvorba kariérového záväzku & $\mathbf{0 , 4 1 0 / -}$ & $<\mathbf{0 , 0 0 1}$ \\
Identifikácia s kariérovým záväzkom & $\mathbf{0 , 5 3 4 / -}$ & $<\mathbf{0 , 0 0 1}$ \\
Kariérový prieskum do šírky & $\mathbf{0 , 4 7 1 / -}$ & $<\mathbf{0 , 0 0 1}$ \\
Kariérový prieskum do hĺbky & $\mathbf{0 , 5 2 6 / -}$ & $<\mathbf{0 , 0 0 1}$ \\
Kariérová sebapochybnost' & - & $<\mathbf{0 , 0 0 1}$ \\
Kariérová flexibilita & $\mathbf{0 , 3 6 3 / -}$ & 0,385 \\
\hline
\end{tabular}

Legenda: $\mathrm{n}$ - počet participantov, $\mathrm{r}_{\mathrm{s}}$ - Spearmanov korelačný koeficient, p - štatistická významnost'.

Medzi adaptívnymi aspektmi pracovnej identity: tvorbou kariérového záväzku, identifikáciou s kariérovým záväzkom, kariérovým skúmaním do šírky a híbky a celkovou kvalitou života sme zistili stredne silné pozitívne štatisticky významné vzt’ahy ( $r=0,410-0,526 ; p<0,001)$. Zistili sme negatívny stredne silný štatisticky významný vzt'ah medzi celkovou kvalitou života a kariérovou sebapochybnost'ou $(r=-0,363 ; p<0,001)$. Medzi kariérovou flexibilitou a celkovou úrovňou kvality života sme však nezistili štatisticky významný vzt'ah. 
Tab 2 Korelácia dimenzií kariérového skúmania a dimenzií hodnotenia spokojnosti s oblast’ami života a ich významnosti $(n=102)$

\begin{tabular}{lcccc}
\hline & \multicolumn{4}{c}{ Kariérové skúmanie } \\
\multicolumn{1}{c}{ Dimenzie kvality života } & skúmanie do šírky & skúmanie do híbky \\
& $\mathrm{r} / \mathrm{r}_{\mathrm{s}}$ & $\mathrm{p}$ & $\mathrm{r} / \mathrm{r}_{\mathrm{s}}$ & $\mathrm{p}$ \\
\hline Spokojnost' - vol'ný čas & $\mathbf{0 , 3 7 5} /-$ & $<\mathbf{0 , 0 0 1}$ & $\mathbf{0 , 4 4 1} /-$ & $<\mathbf{0 , 0 0 1}$ \\
Spokojnost' - základné potreby & $\mathbf{0 , 3 5 2} /-$ & $<\mathbf{0 , 0 0 1}$ & $\mathbf{0 , 2 6 2} /-$ & $\mathbf{0 , 0 0 8}$ \\
Spokojnost' - abstraktné hodnoty & $\mathbf{0 , 4 5 1} /-$ & $<\mathbf{0 , 0 0 1}$ & $\mathbf{0 , 3 2 5} /-$ & $\mathbf{0 , 0 0 1}$ \\
Spokojnost' - blízke vzt'ahy & $\mathbf{0 , 5 7 3} /-$ & $<\mathbf{0 , 0 0 1}$ & $\mathbf{0 , 2 4 2} /-$ & $\mathbf{0 , 0 1 4}$ \\
Spokojnost' - zdravie & $-/ \mathbf{0 , 3 3 6}$ & $<\mathbf{0 , 0 0 1}$ & $-/ \mathbf{0 , 3 8 3}$ & $<\mathbf{0 , 0 0 1}$ \\
Významnost' - vol'ný čas & $0,140 /-$ & 0,159 & $\mathbf{0 , 4 9 5} /-$ & $<\mathbf{0 , 0 0 1}$ \\
Významnost' - základné potreby & $-0,168 /-$ & 0,091 & $-0,94 /-$ & 0,349 \\
Významnost' - abstraktné hodnoty & $\mathbf{0 , 3 2 4} /-$ & $<\mathbf{0 , 0 0 1}$ & $\mathbf{0 , 4 6 1} /-$ & $<\mathbf{0 , 0 0 1}$ \\
Významnost' - zdravie & $-/ 0,171$ & 0,085 & $-/ \mathbf{0 , 4 6 7}$ & $<\mathbf{0 , 0 0 1}$ \\
Významnost' - blízke vzt'ahy & $-/ 0,133$ & 0,182 & $-/ \mathbf{0 , 2 4 4}$ & $\mathbf{0 , 0 1 3}$ \\
\hline Legenda: $n$ - počet participantov, r - Pearsonov korelačný koeficient, $\mathrm{r}_{\mathrm{s}}-$ Spearmanov korelačný koeficient, $\mathrm{p}$ \\
- štatistická významnost'.
\end{tabular}

Zistili sme slabé až stredne silné, štatisticky významné pozitívne vzt'ahy $\left(\mathrm{r} / \mathrm{r}_{\mathrm{s}}=0,242-0,573\right.$; p<0,05) medzi kategóriami pracovnej identity - skúmaním do híbky a do šírky v súvislosti so spokojnost'ou s jednotlivými aspektmi života.

V prípade vzt'ahov, ktoré sme medzi kategóriou pracovnej identity - skúmaním do šírky a významnost'ou jednotlivých aspektov života sme zistili štatisticky významný slabý vzt'ah iba s dôležitost'ou abstraktných hodnôt $(r=0,324 ; p<0,001)$. Čo sa týka vzt'ahov skúmania do híbky a významnosti aspektov života, zistili sme štatisticky významné slabé až stredne silné pozitívne vzt'ahy pri všetkých aspektoch života okrem významnosti základných potrieb $\left(\mathrm{r} / \mathrm{r}_{\mathrm{s}}=0,244-0,495\right.$; $\mathrm{p}<0,05)$.

Tab 1 Korelácia dimenzií kariérového záväzku a dimenzií hodnotenia spokojnosti s oblast'ami života $(n=102)$

\begin{tabular}{llccc}
\hline \multirow{2}{*}{ Dimenzie kvality života } & \multicolumn{4}{c}{ Kariérový záväzok } \\
& \multicolumn{2}{c}{ tvorba záväzku } & \multicolumn{2}{c}{ identifikácia } \\
\cline { 2 - 5 } & $\mathrm{r} / \mathrm{r}_{\mathrm{s}}$ & $\mathrm{p}$ & $\mathrm{r}$ & $\mathrm{p}$ \\
\hline Spokojnost' - vol'ný čas & $\mathbf{0 , 3 4 8} /-$ & $\mathbf{0 , 0 0 1}$ & $\mathbf{0 , 5 5 1} /-$ & $<\mathbf{0 , 0 0 1}$ \\
Spokojnost' - základné potreby & $0,172 /-$ & 0,084 & $\mathbf{0 , 2 7 1} /-$ & $\mathbf{0 , 0 0 6}$ \\
Spokojnost' - abstraktné hodnoty & $\mathbf{0 , 2 8 4} /-$ & $\mathbf{0 , 0 0 4}$ & $\mathbf{0 , 5 1 5} /-$ & $<\mathbf{0 , 0 0 1}$ \\
Spokojnost' - blízke vzt'ahy & $\mathbf{0 , 3 2 1} /-$ & $\mathbf{0 , 0 0 1}$ & $\mathbf{0 , 5 0 0} /-$ & $<\mathbf{0 , 0 0 1}$ \\
Spokojnost' - zdravie & $-/ \mathbf{0 , 5 5 2}$ & $<\mathbf{0 , 0 0 1}$ & $-/ \mathbf{0 , 5 3 1}$ & $<\mathbf{0 , 0 0 1}$ \\
Dôležitost' - vol'ný čas & $\mathbf{0 , 2 2 9} /-$ & $\mathbf{0 , 0 2 1}$ & $\mathbf{0 , 2 0 9} /-$ & $\mathbf{0 , 0 3 5}$ \\
Dôležitost' - základné potreby & $-0,110 /-$ & 0,271 & $-0,162 /-$ & 0,105 \\
Dôležitost' - abstraktné hodnoty & $\mathbf{0 , 2 5 5} /-$ & $\mathbf{0 , 0 1 0}$ & $\mathbf{0 , 3 2 3} /-$ & $\mathbf{0 , 0 0 1}$ \\
Dôležitost' - zdravie & $-/ \mathbf{0 , 2 6 4}$ & $\mathbf{0 , 0 0 7}$ & $-/ \mathbf{0 , 2 2 3}$ & $\mathbf{0 , 0 2 4}$ \\
Dôležitost' - blízke vzt'ahy & $-/ 0,179$ & 0,071 & $-/ 0,174$ & 0,080 \\
\hline
\end{tabular}

Legenda: $\mathrm{n}$ - počet participantov, $\mathrm{r}$ - Pearsonov korelačný koeficient, $\mathrm{r}_{\mathrm{s}}-$ Spearmanov korelačný koeficient, p - štatistická významnost'. 
Zistili sme významné vzt’ahy medzi kategóriou pracovnej identity - tvorbou záväzku v súvislosti so spokojnost'ou s jednotlivými aspektmi života, s výnimkou aspektu spokojnost'- základné potreby. Zistili sme slabé až stredne silné, štatisticky významné pozitívne vzt'ahy $\left(\mathrm{r} / \mathrm{r}_{\mathrm{s}}=0,284\right.$ 0,552; $\mathrm{p}<0,01)$.

Medzi identifikáciou s kariérovým záväzkom v súvislosti so spokojnost’ou s jednotlivými aspektmi života sme zistili slabé až stredne silné, štatisticky významné pozitívne vzt'ahy $\left(\mathrm{r} / \mathrm{r}_{\mathrm{s}}=0,271-0,551\right.$; $\mathrm{p}<0,01)$.

Medzi tvorbou záväzku a identifikáciou s kariérovým záväzkom a významnost’ou s jednotlivými aspektmi života sme identifikovali významné vzt’ahy, okrem vzt’ahov s významnost’ou základných potrieb a blízkych vzt’ahov. Vzt’ahy tvorby záväzku a identifikácie so záväzkom a významnosti vol'ného času, abstraktných hodnôt a zdravia boli štatisticky významné slabé až stredne silné ( $\mathrm{r} / \mathrm{r}_{\mathrm{s}}$ $=0,209-0,323 ; \mathrm{p}<0,05)$.

Tab 4 Korelácia dimenzií kariérového prehodnotenia a dimenzií hodnotenia spokojnosti s oblast’ami života

Kariérové prehodnotenie

\begin{tabular}{lcccc} 
Dimenzie kvality života , $\mathrm{n}=102$ & \multicolumn{2}{c}{ sebapochybnost' } & \multicolumn{2}{c}{ flexibilita } \\
\cline { 2 - 5 } & $\mathbf{r} / \mathbf{r}_{\mathbf{s}}$ & $\mathbf{p}$ & $\mathbf{r}$ & $\mathbf{p}$ \\
\hline Spokojnost' - vol'ný čas & $\mathbf{- 0 , 3 1 2} /-$ & $\mathbf{0 , 0 0 1}$ & $\mathbf{- 0 , 2 9 8}$ & $\mathbf{0 , 0 0 2}$ \\
Spokojnost' - základné potreby & $-0,054 /-$ & 0,586 & $\mathbf{0 , 3 0 1}$ & $\mathbf{0 , 0 0 2}$ \\
Spokojnost' - abstraktné hodnoty & $-0,185 /-$ & 0,062 & 0,041 & 0,679 \\
Spokojnost' - blízke vzt'ahy & $\mathbf{- 0 , 4 9 9} /-$ & $\mathbf{0 , 0 0 1}$ & 0,084 & 0,403 \\
Spokojnost' - zdravie & $-/-\mathbf{- 0 , 4 1 2}$ & $\mathbf{< 0 , 0 0 1}$ & $\mathbf{- 0 , 2 3 1}$ & $\mathbf{0 , 0 2 0}$ \\
Dôležitost' - vol'ný čas & $\mathbf{- 0 , 3 1 0 / -}$ & $\mathbf{0 , 0 0 2}$ & $\mathbf{- 0 , 2 3 4}$ & $\mathbf{0 , 0 1 8}$ \\
Dôležitost' - základné potreby & $0,172 /-$ & 0,084 & 0,152 & 0,126 \\
Dôležitost' - abstraktné hodnoty & $\mathbf{- 0 , 2 0 5 / -}$ & $\mathbf{0 , 0 3 9}$ & $-0,013$ & 0,900 \\
Dôležitost' - zdravie & $-/-\mathbf{0 , 2 2 6}$ & $\mathbf{0 , 0 2 2}$ & $-0,176$ & 0,077 \\
Dôležitost' - blízke vzt'ahy & $-/-0,118$ & 0,237 & $-0,125$ & 0,211 \\
\hline
\end{tabular}

Legenda: $n$ - počet participantov, $r$ - Pearsonov korelačný koeficient, $r_{s}$ - Spearmanov korelačný koeficient, $p$ - štatistická významnost'.

Významné negatívne stredne silné vzt’ahy sme zistili medzi kategóriou pracovnej identity kariérovou sebapochybnost'ou v súvislosti so spokojnost'ou s aspektmi života - vol'ný čas, vzt'ahy a zdravie $\left(r / r_{s}=-0,312--0,499 ; p<0,01\right)$. Vzt'ahy medzi kategóriou pracovnej identity - kariérovou flexibilitou v súvislosti so spokojnost’ou s jednotlivými aspektmi života sme zistili v prípade spokojnosti s vol'ným časom, a zdravím. Zistili sme slabé, štatisticky významné negatívne vzt'ahy $\left(r_{s}=-0,231--0,298 ; p<0,05\right)$. V prípade spokojnosti so základnými potrebami sme zistili stredne silný významný vzt’ah ( $\mathrm{r}_{\mathrm{s}}=0,301 ; \mathrm{p}<0,01$.)

Medzi kariérovou sebapochybnost'ou a významnost'ou jednotlivých aspektov života sme zistili vzt'ahy v prípade významnosti abstraktných hodnôt - zdravia a vol'ného času. Zistili sme slabé až stredne silné štatisticky významné negatívne vzt'ahy $\left(r / r_{s}=-0,205--0,310 ; p<0,05\right)$. V prípade vzt'ahov medzi kariérovou flexibilitou a významnost'ou oblastí života sme zistili iba jeden štatisticky významný negatívny avšak zanedbatel'ný vzt’ah v prípade významnosti vol'ného času ( $\mathrm{r}_{\mathrm{s}}$ $=-0,234 ; \mathrm{p}<0,05)$. 
Graf 1 Zhluková analýza statusov pracovnej identity, výskumný súbor mladých dospelých (n=102)

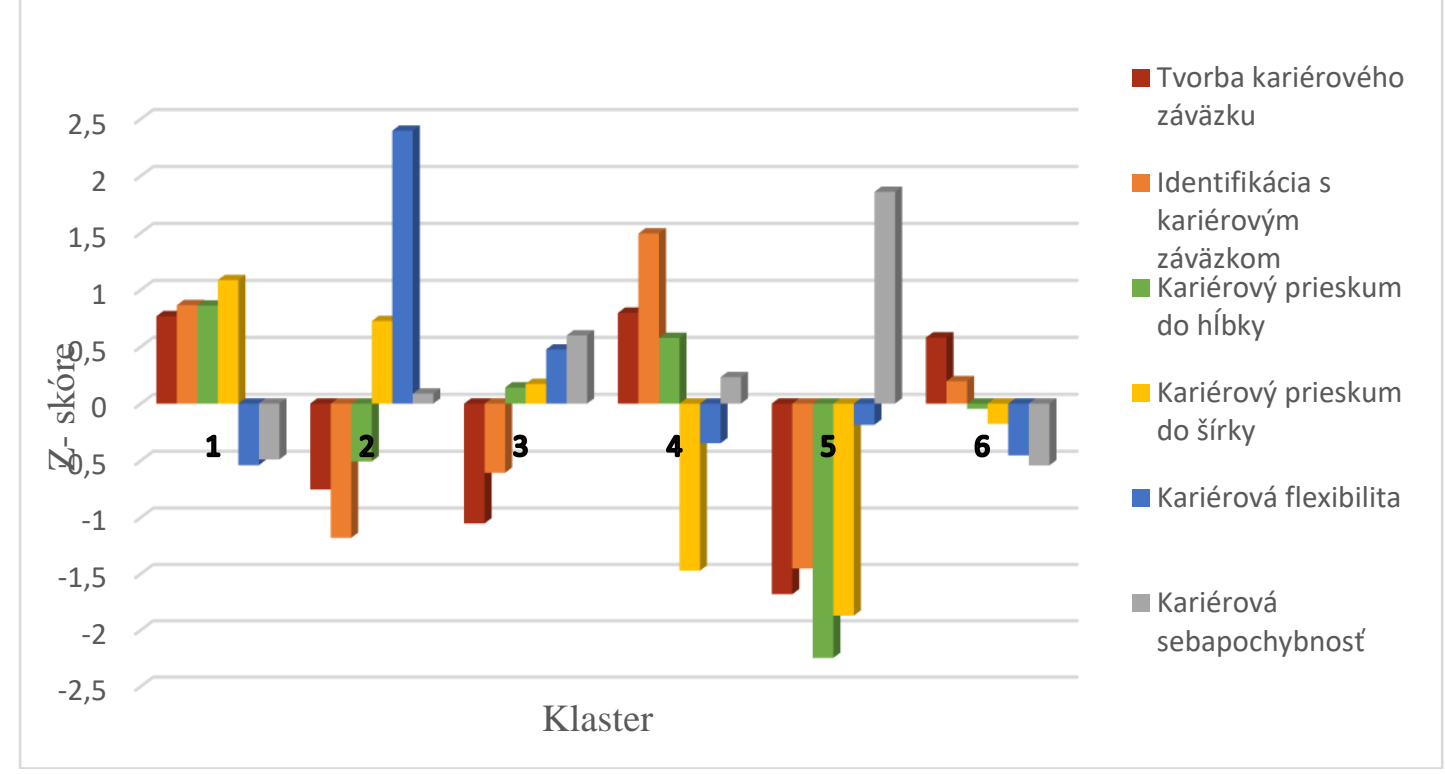

Legenda: 1 - dosiahnutý status, 2 - status moratória v štádiu hladania, 3 - moratórium, 4 -uzavretý status, 5 rozptýlený status, 6 - nediferencovaný status pracovnej identity.

Participanti nachádzajúci sa v dosiahnutom statuse pracovnej identity (1) majú približne rovnako vysoké hodnoty v tvorbe záväzku a identifikácii so záväzkom aj v oboch kategóriách kariérového skúmania. Majú nízku kariérovú flexibilitu a sebapochybnosti, ktorých Z-skóre sú skoro totožné. Participanti v statuse moratória v štádiu hl'adania (2) dosiahli stredovú hodnotu v kariérových sebapochybnostiach, no vel'mi vysoké hodnoty v kariérovej flexibilite. Vysoké hodnoty vykazujú aj v kariérovom prieskume do šírky. Nízke hodnoty dosahujú v kariérovom prieskume do híbky a v tvorbe a identifikácii s kariérovým záväzkom. Participanti v statuse moratória (3) majú nízke hodnoty tvorby a identifikácie so záväzkom. Hodnoty oboch kategórii skúmania sú vyššie, no blízke stredovým hodnotám. V kariérovom prehodnotení v obidvoch kategóriách dosahujú participanti vysoké hodnoty. Status uzavretej pracovnej identity (4) sa vyznačuje vysokými hodnotami v kariérovom záväzku, pričom vel’mi vysoké hodnoty sú v identifikácii so záväzkom. Ide o najvyššie hodnoty identifikácie spomedzi ostatných statusov. Vysoké hodnoty dosahujú v prieskume do híbky, naopak vel'mi nízke hodnoty dosahujú v prieskume do šírky. Pri flexibilite a rovnako pri sebapochybnostiach dosahujú stredné hodnoty. Participanti v rozptýlenom statuse pracovnej identity (5) majú vel'mi nízke hodnoty v tvorbe aj v identifikácii so záväzkom, rovnako v prieskume do šírky aj do híbky. Stredné hodnoty majú v kariérovej flexibilite. Respondenti majú vel'mi vysoké hodnoty v kariérových sebapochybnostiach, ktoré sú najvyššie spomedzi ostatných statusov. A nakoniec participanti v nediferencovanom statuse pracovnej identity (6) dosiahli vysoké hodnoty v tvorbe kariérového záväzku. Stredové hodnoty v identifikácií so záväzkom, v prieskume do híbky aj do šírky. Nízke hodnoty dosiahli vo flexibilite i sebapochybnostiach. 
Pomáhajúce profesie, roč. 2, č. 1, 2019, 37-52

Tab 5 Rozloženie statusov pracovnej identity vo výskumnom súbore mladších dospelých $(n=102)$

\begin{tabular}{cc}
\hline Status pracovnej identity & n (\%) \\
\hline Dosiahnutý status & $20(19,61 \%)$ \\
Moratórium v štádiu hl'adania & $9(8,82 \%)$ \\
Moratórium & $21(20,60 \%)$ \\
Uzavretý status & $7(6,86 \%)$ \\
Rozptýlený status & $8(7,84 \%)$ \\
Nediferencovaný status & $37(36,27 \%)$ \\
\hline
\end{tabular}

Najväčší počet respondentov, a to viac než tretina $(36,27 \%)$ sa nachádzal v nediferencovanom statuse pracovnej identity, druhým najviac zastúpeným statusom bol status moratória $(20,60 \%)$ a hned' za ním dosiahnutý status pracovnej identity $(19,61 \%)$. Najmenej zastúpeným statusom v našom výskumnom súbore bol uzavretý status (6,86\%) a tesne za ním rozptýlený status pracovnej identity $(7,84 \%)$.

\section{DISKUSIA}

Zámerom našej práce bolo zistit' súvislost’ medzi pracovnou identitou a kvalitou života v populácii mladších dospelých, ktorí sú zapojení do pracovného procesu. Teoreticky sme vychádzali z modelu pracovnej identity podl’a Porfeliho (2011), ktorý delí pracovnú identitu na tri dimenzie, ktorými sú kariérový záväzok, kariérové skúmanie a kariérové prehodnotenie. Vychádzali sme pritom z kombinovaného modelu kvality života, ktorý chápe kvalitu života ako subjektívny pohl'ad jednotlivca na jeho život vrátane hodnotenia toho, do akej miery je spokojný s oblast'ami života, ktoré sú pre neho významné a dôležité (Babinčák, 2008).

\subsection{Vzt́ah pracovnej identity a kvality života}

Na základe výsledkov usudzujeme, že medzi pracovnou identitou a kvalitou života existuje vzájomná súvislost', aj napriek tomu že kariérová flexibilita sa nepreukázala ako významná vo vzt'ahu ku kvalite života. Nemôžeme však potvrdit' súvislost' medzi vnímaním kvality života a kariérovou flexibilitou u mladších dospelých. Tá je sprevádzaná neustálym, opakovaným, aktívnym rozmýšlaním o alternatívach, rovnako je typická otvorenost’ou k zmenám záujmov či pracovných príležitosti a prijatím toho, že záujmy, hodnoty aj výber kariéry sa v budúcnosti môžu zmenit' (Porfeli, Lee, Vondracek, \& Weigold, 2011; Porfeli, \& Savickas, 2012).

S kvalitou života pozitívne súvisí pocitovanie istoty s výberom danej kariéry, ktorá je charakteristická pre tvorbu kariérového záväzku. Kariérový záväzok je dôležitý pre celkovú subjektívnu pohodu u l'udí, ktorí sa chcú usadit' v zamestnaní (Demirtas, Tezer, 2012). Kvalita života je tiež pozitívne spojená s prieskumnou činnost'ou zameranou na prehlbovanie vedomostí o možnostiach výberu kariéry, o možnostiach konkrétneho zamestnania, či o spôsobe prispôsobovania sa danému povolaniu. Aj táto súvislost' sa ukázala ako stredne silná. Človek, ktorý má viac informácií o možnostiach kariéry hodnotí svoj život ako kvalitnejší. Uvažujeme, že u človeka, ktorý má viac informácií o svojich schopnostiach, ktoré sú v súlade $\mathrm{s}$ danou kariérou je vyššie hodnotenie jeho kvality života, pretože schopnost' skúmat' svoje prostredie aj seba samého je základnou a dôležitou podmienkou zdravia aj pohody (Oleś, 2015). 
Sebapochybnosti týkajúce sa kariéry, ktoré sú sprevádzané pochybovaním, neistotou, úzkost'ou a strachom zo súčasného výberu kariéry negatívne súvisia s hodnotením kvality života. Človek, ktorý je viac neistý, vystrašený, znepokojený svojím súčasným výberom kariéry, hodnotí svoj život ako menej kvalitný. Zistenia sú v súlade so zisteniami výskumníkov (Hirchi, 2012; Karaś, Cieciuch, 2018; Luyckx., Schwartz, Berzonsky, Soenens, Vansteenkiste, Smits, \& Goossens, 2008; Oleś, 2015).

\subsection{Vzt’ah kariérového skúmania a hodnotenie významnosti a spokojnosti s oblast’ami života}

Na základe našich zistení môžeme usudzovat', že kariérové skúmanie do šírky i do híbky má pozitívny vzt’ah so všetkými oblast'ami hodnotenia spokojnosti. Zist'ovanie informácii o možnostiach kariéry, a rovnako o vlastných schopnostiach pozitívne súvisí s hodnotením spokojnosti so zdravím, blízkymi vzt'ahmi, základnými potrebami, abstraktnými hodnotami i vol'ným časom. Zistenia sú v rozpore so zistením Demirtasovej a Tezerovej (2012), ktoré poukázali na negatívny vzt’ah medzi romantickými vzt'ahmi a kariérovým prieskumom. Ale naopak Karaś a Cieciuch (2018) zistili, že medzi rodinnými vzt’ahmi a kariérovým skúmaním do híbky je pozitívny vzt'ah. Taktiež tvrdia, že koníčky a záujmy sú v pozitívnej súvislosti s hlbokým kariérovým skúmaním. Rovnaké sú aj naše zistenia v oblasti blízke vzt'ahy a vol'ný čas.

Zistenia týkajúce sa vzt’ahu medzi kariérovým prieskumom a hodnotením dôležitosti daných oblastí života nie sú jednoznačné. V prípade hodnotenia dôležitosti sa preukázal vzt’ah medzi kariérovým skúmaním do šírky a jedinou oblast'ou života a to, hodnotenie dôležitosti abstraktných hodnôt. Výsledky potvrdili vzt’ah medzi kariérovým skúmaním do hĺbky a hodnotením dôležitosti vol'ného času, blízkych vzt'ahov, abstraktných hodnôt a zdravia. Vo všetkých prípadoch išlo o pozitívnu súvislost'. Uvažujeme teda spôsobom, že čím viac detailne sa vybranou kariérnou možnost'ou mladý človek zaoberá, tým hodnotí ako dôležitejšie vol'ný čas, fyzickú sebestačnost' či psychickú pohodu a vzt'ahy s rodinou.

\subsection{Vzt’ah kariérového záväzku a hodnotenie významnosti a spokojnosti s oblast’ami života}

Kariérový záväzok je v pozitívnej súvislosti s hodnotením spokojnosti stakmer všetkými oblast'ami života, čiže s vol'ným časom, blízkymi vzt'ahmi, abstraktnými hodnotami, zdravím a základnými potrebami. Aj v tomto prípade je naše zistenie v rozpore s výsledkami Demirtasovej a Tezerovej (2012), ktoré hovoria o negatívnej súvislosti medzi romantickými vzt'ahmi a záväzkom ku kariére. Výskum Gouleta a Singha (2002) poukázal na to, že medzi kariérovým záväzkom a angažovanost'ou rodiny neexistuje súvislost'. Ale naše výsledky potvrdzujú výsledky Karaśa a Cieciucha (2018), ktorí tvrdia, že rodinné vzt'ahy aj koníčky a záujmy pozitívne súvisia s kariérovým záväzkom.

Pri hodnotení dôležitosti oblasti života sa nám vo vzt’ahu ku kariérovému záväzku preukázal vzt’ah len s troma oblast’ami života. Významný pozitívny vzt'ah existuje medzi kariérovým záväzkom a hodnotením dôležitosti vol'ného času, abstraktných hodnôt a zdravia. Vyšší pocit istoty a väčšie stotožnenie sa s kariérou súvisí s vyšším hodnotením dôležitosti spôsobu trávenia vol'ného času, vnímania dôležitosti abstraktných hodnôt a dôležitosti zdravia. Ďalšie dve oblasti života, základné potreby a blízke vzt'ahy, nesúvisia s kariérovým záväzkom.

Zo vzt’ahov s dimenziami kariérového záväzku vyplýva, že l’udia stotožnení so svojou prácou nepovažujú blízke vzt’ahy za dôležité. Ale stotožnenie sa s prácou pozitívne súvisí so spokojnost'ou s blízkymi vzt'ahmi. Vysvetlenie môžu ponúknut' rozporuplné zistenia, a to, že požiadavky rodiny môžu spôsobit’ zníženie záväzku ku kariére (Goulet, Singh, 2002), avšak funkčné rodinné systémy sú primárnou podporou pre pracovnú identitu (Shin, Kelly, 2013).

\subsection{Vzt’ah kariérového prehodnotenia, významnosti a spokojnosti s oblast’ami života}


Karaś a Cieciuch (2018) nezistili spojenie kariérového prehodnotenia s rodinnými vzt'ahmi ani s koníčkami a záujmami. Rovnako sme ani my nezistili prepojenie kariérového prehodnotenia a blízkych vzt’ahov. Narozdiel od ich zistenia týkajúceho sa koníčkov a záujmov, sme zistili negatívne prepojenie vol'ného času a kariérového prehodnotenia. Zistenia poukazujú na to, že vyššia úzkost' a neistota vo výbere kariéry a aktívne zvažovanie alternatívnych možností súvisia s horším vnímaním spokojnosti s vol'ným časom i so zdravím. Negatívny, stredne silný vztah existuje medzi dimenziou kariérová sebapochybnost' a hodnotením spokojnosti s blízkymi vzt’ahmi. V pracovnej identite zohrávajú dôležitú úlohu dobré rodinné vzt’ahy a rodina (Shin, Kelly, 2013). Väčšia neistota a úzkost' z kariérovej vol'by má súvislost' s nižším hodnotením spokojnosti s rodinnými vzt’ahmi. Pozitívna, avšak slabá súvislost’ existuje medzi kariérovou flexibilitou a hodnotením spokojnosti so základnými potrebami. Čo poukazuje na to, že aktívnejšie zvažovanie alternatívnych možností, týkajúcich sa kariéry, súvisí s vyšším hodnotením spokojnosti so základnými potrebami.

Pri hodnotení významnosti oblastí života sa preukázal vzt'ah medzi oboma kategóriami kariérového prehodnotenia a hodnotením významnosti vol'ného času, medzi kariérovou sebapochybnost'ou a hodnotením dôležitosti zdravia a abstraktných hodnôt. Vo všetkých týchto prípadoch išlo o negatívny, slabý vzt'ah. Tieto zistenia poukazujú na to, že nižšia úzkost', neistota týkajúca sa aktuálnej kariérovej vol'by súvisí s vyšším hodnotením dôležitosti zdravia a abstraktných hodnôt ako napríklad slobody. Nižšie kariérové prehodnotenie súvisí s vyšším hodnotením dôležitosti vol'ného času.

\subsection{Statusy pracovnej identity vo výskumnom súbore mladších dospelých}

Výsledky zhlukovej analýzy sú vel'mi podobné výsledkom na americkej vzorke v štúdii, ktorú realizovali Porfeli, Lee, Vondracek, a Weigold (2011). Z analýzy slovenského výskumného súboru vyplýva, že mladí l'udia, ktorí dozreli do statusu pracovnej identity, mali jasný záväzok ku kariére po tom, čo aktívne preskúmali d’alšie možné alternatívy a súčasne mali nízke prehodnocovanie svojich záväzkov. Tí, ktorí sú v statuse moratória v štádiu hl'adania, stále prehodnocovali svoju kariéru a výber povolania, pretože neboli identifikovaní s povolaním a neustále hl'adali nové alternatívy, no neskúmali ich do hĺbky, je zrejmé že boli viac ochotní k zmene vybranej kariéry. Participanti v moratóriu nemali vytvorený záväzok ku kariére, a teda neboli s ním identifikovaní, nevenovali sa dostatočne skúmaniu možných povolaní, avšak mali značné pochybnosti o kariére a boli otvorení k zmenám kariéry. Status uzavretej pracovnej identity je daný, vytvorením si záväzku ku kariére a vysokým stotožnením sa so záväzkom, súčasne so skúmaním povolania do hĺbky, avšak nízkym prieskumom d’alších alternatív, neochotou ku zmene kariéry a určitými pochybnost’ami o kariére. Participanti v rozptýlenom statuse pracovnej identity nemali vytvorený kariérový záväzok, ani neboli stotožnení so záväzkom ku kariére, neskúmali možnosti kariéry, neboli úplne otvorení k zmene kariéry, avšak prechovávali značnú neistotu a pochybnosti o svojej kariére. Nediferencovaný status popisuje l’udí, ktorí mali vytvorený záväzok ku kariére a boli s ním stotožnení, nevykonávali činnosti zamerané na skúmanie kariéry a neboli ochotní k zmene kariéry, nepocit'ovali pochybnosti o výbere svojej kariéry.

Tretina participantov sa nachádza v nediferencovanom statuse pracovnej identity. Napriek tomu, že ide o pracujúcich mladších dospelých, u ktorých by sa očakávalo, že ich pracovná identita bude vdosiahnutom statuse. Dokonca viac participantov sa nachádza v statuse moratória ako $\mathrm{v}$ dosiahnutom statuse pracovnej identity. Tento výsledok nás vedie $\mathrm{k}$ úvahe, že pracovná identita je dynamický proces ako si to myslí aj Oleśová (2015). Porfeli a Lee (2012) poukazujú na to, že súčasnost' uprednostňuje flexibilný a sebareflexívny prístup ku kariérovým záväzkom.

$\mathrm{Na}$ druhej strane nás to privádza k zamysleniu sa či to, že sa naši participanti nachádzajú v nediferencovanom statuse nie je dané tým, že so svojou súčasnou kariérou sú spokojní a nechcú 
ju menit'. Teda sú stotožnení so svojou kariérou, nie sú otvorení k zmene kariéry. Vysvetlením vyššieho počtu participantov nachádzajúcich sa v statuse moratória môže byt' zbieranie pracovných skúsenosti a „hl'adanie toho správneho povolania“.

\subsection{Limity}

Obmedzením týkajúcim sa výskumného súboru je nerovnomerné zastúpenie pohlavia. V našom výskumnom súbore prevládali ženy, ktorých bolo 57, pričom mužov bolo 45 . Vzorka nebola vyvážená ani z pohl'adu zamestnanosti. $V$ našej vzorke výrazne prevládali zamestnaní participanti v počte 89 oproti 11 nezamestnaným participantom. Uvedomujeme si, že naša výskumná vzorka nie je dostačujúca $\mathrm{z}$ hl'adiska vel'kosti $\mathrm{n}=102$.

Pre realizáciu nášho výskumu sme zvolili korelačnú analýzu. Sme si vedomí toho, že nami zvolený dizajn nám umožňuje konštatovat' súvislost' medzi premennými, no neumožňuje nám konštatovat' závislost' premenných. Nemôžeme teda jednoznačne tvrdit', že kvalita života závisí od pracovnej identity, môžeme sa zmienit’ len o súvislosti daných premenných.

\subsection{Prínos štúdie a odporúčania pre d’alšie skúmanie}

Za prínos našej práce považujeme detailné zmapovanie vzt’ahu medzi pracovnou identitou a kvalitou života mladších dospelých, na úrovni jednotlivých dimenzií oboch premenných. Významným v našej práci je najmä zistenie, ktoré oblasti života, a teda hodnotenie ich významnosti a spokojnosti s nimi, súvisí s jednotlivými dimenziami pracovnej identity.

V našej práci sme chceli zistit’ vzt’ah medzi premennými v populácii mladších dospelých, ktorí ako vzorka doteraz neboli v slovenskom výskumnom kontexte zaradení do výskumov týkajúcich sa pracovnej identity. Výskum v budúcnosti možno zamerat' na porovnanie pracovnej identity u rôznych povolaní, existenciu významných rozdielov medzi jednotlivými povolaniami. Iným nemenej dôležitým zameraním výskumu by mohlo byt' skúmanie pracovnej identity v populácii dlhodobo nezamestnaných, vrátane ich porovnania s pracujúcou populáciou. Zmienený typ štúdie by poskytol komplexnejší obraz o živote dlhodobo nezamestnaných.

\section{ZÁVER}

Z výsledkov usudzujeme, že skúmanie vlastných možností kariéry, svojich vlastností v kontexte kariéry, vytváranie záväzku voči kariére a identifikácia s týmto záväzkom, pozitívne súvisí so subjektívnou kvalitou života mladších dospelých. Rovnako strach, úzkost', neistota a pochybnosti o výbere kariéry negatívne súvisia so subjektívnou kvalitou života u mladších dospelých.

Podrobne sme popísali vzt’ah medzi jednotlivými kategóriami pracovnej identity a hodnotením spokojnosti a významnosti piatich oblastí života: zdravie, základné potreby, abstraktné hodnoty, blízke vzt’ahy a vol'ný čas. Zistenia ukazujú, že kariérové skúmanie aj záväzok sú pozitívne spojené so spokojnost'ou so všetkými oblast'ami života. Spokojnost' v osobnom živote človeka súvisí s jeho získavaním informácií o sebe i o kariére a taktiež aj s jeho záväzkom ku kariére. Opakované premýšl'anie o výbere kariéry sa negatívne podpisuje pod vnímanie spokojnosti so zdravím, vol’ným časom aj blízkymi vzt’ahmi. Klúčovými oblast'ami života vo vzt’ahu ku všetkým aspektom pracovnej identity, z hl'adiska spokojnosti sú zdravie, vol'ný čas a blízke vzt'ahy.

Pre človeka, ktorý sa hlbšie zaoberá zist'ovaním svojich vlastnosti vzhl'adom ku kariére, sú dôležitými oblast'ami zdravie, vol'ný čas, abstraktné hodnoty aj blízke vzt'ahy. Človek, ktorý má vytvorený záväzok ku kariére a je s ním dostatočné stotožnený, vo svojom živote považuje za dôležitú oblast' zdravia, vol'ného času a abstraktných hodnôt. Zásadné oblasti života pre záväzok 
a prieskum, z hl'adiska ich dôležitosti sú zdravie, vol'ný čas a abstraktné hodnoty. Opakované prehodnocovanie kariéry súvisí s negatívnym vnímaním dôležitosti vol’ného času.

Výsledky zhlukovej analýzy ukázali, že tretina našich participantov sa nachádza v statuse nediferencovanej pracovnej identity, Zistenie môže poukazovat' na to, že naši participanti nemajú vytvorenú predstavu o tom, čo by chceli v živote robit'. Iným vysvetlením by mohlo byt' to, že súčasná práca im vyhovuje a neuvažujú o jej zmene. Značné zastúpenie participantov v statuse moratória zas vypovedá o tom, že mladí l’udia sú na začiatku svojej pracovnej kariéry kde ešte len zbierajú pracovné skúsenosti a zist'ujú, čo by pre nich bolo najlepšie.

Význam štúdie vidíme v podrobnom popísaní vzt’ahu medzi jednotlivými dimenziami pracovnej identity a hodnotením spokojnosti a významnosti jednotlivých oblastí života, ktorými sú zdravie, vol'ný čas, abstraktné hodnoty, základné potreby a blízke vzt’ahy.

\section{LITERATÚRA}

Babinčák, P. (2008). Definície, teoretické modely a indikátory kvality života. In Bačová, V. 2008, Kvalita života a sociálny kapitál - Psychologické dimenzie. (42-71). Prešov: Filozofická fakulta Prešovskej univerzity v Prešove.

Babinčák, P. (2013). Porovnanie troch spôsobov hodnotenia subjektívnej kvality života. In Murgaš, F., Prostorové dimenzie kvality života (18-27). Liberec: Technická univerzita v Liberci.

Baňasová, K., Sollár, T., \& Sollárová, E. (2016). Vocational identity in the context of values and career motivation. Psychology Applications \& Developments II Advances in Psychology and Psychological Trends Series, 116.

Carlsson, J., Wängqvist, M., \& Frisén, A. (2016). Life on hold: Staying in identity diffusion in the late twenties. Journal of Adolescence, 47, 220-229.

Crocetti, E., Avanzi, L., Hawk, S. T., Fraccaroli, F., \& Meeus, W. (2014). Personal and social facets of job identity: A person-centered approach. Journal of Business and Psychology, 29(2), 281-300.

Crocetti, E. - Rubini, M. - Meeus, W. (2008). Capturing the dynamics of identity formation in various ethnic groups: Development and validation of a three-dimensional model. Journal of Adolescence, 31, 207-222.

De Goede, M., Spruijt, E., Iedema, J., \& Meeus, W. (1999). How do vocational and relationship stressors and identity formation affect adolescent mental health? Journal of Adolescent Health, 25(1), 14-20.

Demirtas, S. C., \& Tezer, E. (2012). Romantic relationship satisfaction, commitment to career choices and subjective well-being. Procedia - Social and Behavioral Sciences, 46, 2542-2549.

Dimitrova, R., Buzea, C., Taušová, J., Uka, F., Zakaj, S., \& Crocetti, E. (2018). Relationships between identity domains and life satisfaction in minority and majority youth in Albania, Bulgaria, Czech Republic, Kosovo, and Romania. European Journal of Developmental Psychology, 15(1), 61-82.

Erikson, E. H. (1959). Identity and the life cycle: Selected papers. Psychological Issues, 1, 1-171.

Gati, I., Krausz, M., \& Osipow, S. H. (1996). A taxonomy of difficulties in career decision making. Journal of counseling psychology, 43(4), 510.

Goulet, L. R., \& Singh, P. (2002). Career Commitment: A Reexamination and an Extension. Journal of Vocational Behavior, 61, 73-91. 
Hirschi, A. (2011). Vocational Identity as a Mediator of the Relationship between Core SelfEvaluations and Life and Job Satisfaction. Applied Psychology, 60(4), 622-644.

Hirschi, A. (2012). Vocational Identity Trajectories: Differences in Personality and Development of Well-being. European Journal of Personality, 26, 2-12.

Holland, J. L. (1997) Making Vocational Choices: A Theory of Vocational Personalities and Work Environments. 3rd edition, Odessa: Psychological Assessment Resources.

Holland, J. J., Gottfredson, D. C., \& Power, P. G. (1980). Some diagnostic scales for research in decision making and personality: Identity, information, and barriers. Journal of Personality and Social Psychology, 39(6), 1191.

Hudáková, M., \& Sollár, T. (2018). Konštruktová validita Multimetódovej objektívnej testovej batérie záujmov (moi). In Řehan V., Lečbych M, PhD Existence 2018: Sborník př́spěvků: nekonečno v psychologii (110-123). Olomouc: Univerzita Palackého v Olomouci.

Chrastina, J., Ivanová, K., Krejčířová, O., \& Ježorská, Š. (2014). Výzkumy subjektivní kvality života SQUALA standardizovaným dotazníkem. Profese Online, 7(1), 1-8.

Karaś, D., \& Cieciuch, J. (2018). The relationship between identity processes and well-being in various life domains. Personality and Individual Differences, 121, 111-119.

Luyckx, K., Schwartz, S. J., Berzonsky, M. D., Soenens, B., Vansteenkiste, M., Smits, I., \& Goossens, L. (2008). Capturing ruminative exploration: Extending the four-dimensional model of identity formation in late adolescence. Journal of Research in Personality, 42(1), 58-82.

Luyckx, K., Goossens, L., Soenens, B., Beyers, W., \& Vansteenkiste, M. (2005). Identity statuses based on 4 rather than 2 identity dimensions: Extending and refining Marcia's paradigm. Journal of youth and adolescence, 34(6), 605-618.

Malanchuk, O., Messersmith, E. E., \& Eccles, J. S. (2010). The ontogeny of career identities in adolescence. New directions for child and adolescent development, 2010(130), 97-110.

Marcia, J. E. (1966). Development and validation of ego identity status. Journal of Personality and Social Psychology, 3(5), 551-558.

Oleś, M. (2015). Dimension of identity and subjective quality of life in adolescents. Social Indicators Research, 126, 1401-1419.

Porfeli, E. J., Lee, B., Vondracek, F. W., \& Weigold, I. K. (2011). A multidimensional measure of vocational identity status. Journal of adolescence, 34(5), 853-871.

Porfeli, E. J. (2011). Vocational Identity Status Assessment (VISA). 3 p.

Porfeli, E. J., Lee, B. (2012). Career development during childhood and adolescence. New Directions for Youth Development, 134, 11-22.

Porfeli, E. J., \& Savickas, M. J. (2012). Career Adapt-Abilities Scale-USA Form: Psychometric properties and relation to vocational identity. Journal of Vocational Behavior, 80, 748-753.

Saka, N., Gati, I., \& Kelly, K. R. (2008). Emotional and personality-related aspects of career-decisionmaking difficulties. Journal of Career Assessment, 16(4), 403-424.

Smitina, A. (2010). The link between vocational identity, study choice motivation and satisfaction with studies. Procedia-social and behavioral sciences, 5, 1140-1145. 
Super, D. E. (1974). Measuring vocational maturity for counseling and evaluation. Washington DC: National Vocational Guidance Association.

Super, D. E. (1980). A life-span, life-space approach to career development. Journal of vocational behavior, 16(3), 282-298.

Shin, Y., \& Kelly, K. R. (2013). Cross-Cultural Comparison of the Effects of Optimism, Intrinsic Motivation, and Family Relations on Vocational Identity. The Career Development Quarterly, 61, 141-160.

Švehlíková, L., \& Heretik, A. ml. (2008). Kvalita života - o čom to hovoríme? PsychiatriaPsychoterapia-Psychosomatika, 15(3), 194-198.

Veenhoven, R. (2000). The four qualities of life. Journal of happiness studies, 1(1), 1-39.

Zanotti M, Pringuey D. A method for quality of life assessment in psychiatry: the S-QUA-L-A (Subjective QUAlity of Life Analysis). Qual Life News Letter. 4(6).

\title{
SATISFACTION AND IMPORTANCE - ASPECTS OF QUALITY OF LIFE AND VOCATIONAL IDENTITY OF YOUNGER ADULTS
}

\begin{abstract}
The basic concept of our study is the model of vocational identity by Porfeli (2011). Concerning quality of life we based on concepts, which perceived it as assessing importance and satisfaction with areas of life. It was about the rating of satisfaction and importance with five areas of life: health, free time, basic needs, abstract values and close relations. The aim of the research was to identify relationship between quality of life and vocational identity of younger adults population. The research sample consists of 102 participants ( 57 women, 45 men) in the age of 20-30 $(M=24,7, S D=3,11)$. The vocational identity measurement was implemented by Vocational Identity Status Assessment (VISA) questionnaire. For measuring the quality of life we used Subjective Quality of Life Analysis (SQUALA) questionnaire. There are a relationship between vocational identity and quality of life. There is a positive relationship between both of the categories of career commitment and career exploration and quality of life. There was a negative relationship between self-doubt and quality of life. There was no statistically significant relationship between flexibility and quality of life. We found a relationship between some categories of career exploration, commitment, reconsideration and assessing of importance and satisfaction with some areas of life.
\end{abstract}

Keywords: importance, satisfaction, quality of life, vocational identity

Grantová podpora:

Príspevok vznikol ako súčast' riešenia grantových projektov APVV-0540-12 - Psychometrická kvalita psychodiagnostických nástrojov v kariérovom poradenstve a UGA IX/1/2019 Faktory efektívneho rozhodovania študentov podl'a Teórie kognitívneho spracovania informácií v oblasti kariérového poradenstva. 